\title{
PERANAN INTELLECTUAL CAPITAL PADA INTERMEDIARY FUNCTION TERHADAP RETURN ON EQUITY PERUSAHAAN PERBANKAN
}

\author{
Anita Permatasari \\ Program Studi Akuntansi Universitas Katolik Darma Cendika \\ Jl. Dr. Ir. H. Soekarno 201, Surabaya \\ Email: an_n1t4@yahoo.com
}

\begin{abstract}
This study aims to examine the role of Intellectual Capital in banking companies listed on the Indonesia Stock Exchange. The research data used are secondary data in the form of financial data and financial ratios of banks listed on the Indonesia Stock Exchange from 2010 to 2016 using the purposive sampling method. Based on sampling criteria, 23 banks were selected and divided into two categories: banks with low Intellectual Capital and banks with high Intellectual Capital. The results showed that there were three findings, namely the first test results on banks with low Intellectual Capital and high Intellectual Capital showed that Non Performing Loans (NPL), Operational Costs Per Operating Income (BOPO), Loan to Deposit Ratio (LDR), and Capital Adequacy Ratio (CAR) does not affect Return on Equity (ROE). Second, the results of testing on banks with low Intellectual Capital and high Intellectual Capital indicate that Non Performing Loans (NPL), Loan to Deposit Ratio (LDR), and Capital Adequacy Ratio (CAR) have no effect on Return on Equity (ROE). Third, the results of testing on banks with high Intellectual Capital indicate that Operational Cost Per Operational Income (BOPO) has an effect on Return on Equity (ROE).
\end{abstract}

Keywords: Non Performing Loans (NPL), Operational Costs Per Operating Income (BOPO), Loan to Deposit Ratio (LDR), Capital Adequacy Ratio (CAR).

\begin{abstract}
ABSTRAK
Penelitian ini bertujuan untuk menguji peran Intellectual Capital dalam perusahaan perbankan yang terdaftar di Bursa Efek Indonesia. Data penelitian yang digunakan adalah data sekunder berupa data keuangan dan rasio keuangan bank yang terdaftar di Bursa Efek Indonesia dari 2010 hingga 2016 menggunakan metode purposive sampling. Berdasarkan kriteria pengambilan sampel, 23 bank dipilih dan dibagi menjadi dua kategori: bank dengan Intellectual Capital rendah dan bank dengan Intellectual Capital tinggi. Hasil penelitian menunjukkan bahwa terdapat tiga temuan, yaitu hasil tes pertama pada bank dengan Intellectual Capital rendah dan Intellectual Capital tinggi menunjukkan bahwa Non Performing Loans (NPL), Biaya Operasional Per Pendapatan Operasional
\end{abstract}


(BOPO), Loan to Deposit Ratio (LDR), dan Capital Adequacy Ratio (CAR) tidak mempengaruhi Return on Equity (ROE). Kedua, hasil pengujian pada bank dengan Intellectual Capital rendah dan Intellectual Capital tinggi menunjukkan bahwa Non Performing Loans (NPL), Loan to Deposit Ratio (LDR), dan Capital Adequacy Ratio (CAR) tidak berpengaruh pada Return on Equity (ROE). Ketiga, hasil pengujian pada bank dengan Intellectual Capital tinggi menunjukkan bahwa Biaya Operasional Per Pendapatan Operasional (BOPO) memiliki efek pada Return on Equity (ROE).

Kata kunci: Kredit Bermasalah, Biaya Operasional Per Pendapatan Operasional, Rasio Pinjaman terhadap Deposito, Rasio Kecukupan Modal.

\section{PENDAHULUAN}

Bank memiliki peranan penting dalam menunjang perekonomian suatu negara (Permatasari, 2018). Perkembangan bank yang efisien dan efektif dapat mendorong pertumbuhan ekonomi yang berkualitas (Bencivenga and Smith, 1991; Leland and Pyle, 1997; Rajan and Zingales, 1998). Bank juga memiliki karakteristik yang berbeda apabila dibandingkan dengan industri lainnya, sehingga bank memerlukan regulasi dan peraturan perundang-undangan yang jelas untuk menuju persaingan yang sehat (Ariyanto, 2004).

Persaingan yang sehat pada bank dapat tercermin dari kinerja keuangan yang dimiliki oleh bank, salah satunya dapat dilihat dari Return on Equity (ROE). Return on Equity merupakan salah satu rasio keuangan yang menunjukkan nilai profitabilitas bagi para investor (Kabajeh et al., 2012). Selain itu, bank juga perlu dievaluasi secara berkelanjutan demi menghadapi tingkat persaingan ketat yang terjadi antar bank. Ada dua strategi utama bank yaitu loan driven dan deposit driven (Koch and MacDonald, 2014: 169170), di mana loan driven pada perbankan sering dikaitkan dengan fungsi utama bank yaitu sebagai perantara keuangan (financial intermediary), dan deposit driven pada perbankan sering dikaitkan dengan fee based income. Indikator yang digunakan dalam pengukuran intermediary function pada bank ada empat macam yaitu Non Performing Loan (NPL), Biaya Operasional Per Pendapatan Operasional (BOPO), Loan to Deposit Ratio (LDR), dan Capital Adequacy Ratio (CAR).

Non Performing Loan mencerminkan jumlah kredit macet pada bank. Semakin tinggi Non performing Loan, maka semakin besar kondisi bermasalah suatu bank. Oleh karena itu, bank harus melakukan tindakan untuk meminimalkan risiko yang ada seperti penjadwalan, persyaratan, penataan ulang untuk memperkecil risiko kredit (Ali, 2004). Penelitian yang dilakukan oleh Sufian (2011) menunjukkan bahwa variabel Non Performing Loan berpengaruh secara positif pada kinerja keuangan. Sedangkan hasil penelitian dari Constantinos and Sofoklis (2009) menunjukkan bahwa Non Performing Loan berpengaruh negatif terhadap kinerja.

Biaya Operasional terhadap Pendapatan Operasional (BOPO) mencerminkan kemampuan manajer bank 
dalam mengelola kegiatan operasional bank. Biaya operasional terhadap pendapatan operasional yang rendah mencerminkan keefektifan kinerja manajemen bank dalam memanfaatkan sumber daya yang ada untuk meningkatkan kinerja bank. Penelitian yang dilakukan oleh Sinaga (2011) menunjukkan Biaya Operasional terhadap Pendapatan Operasional berpengaruh secara signifikan positif terhadap kinerja keuangan. Hasil penelitian berbeda dikemukakan oleh Sidabutar (2007), Setyarini (2009), Constantinos and Sofoklis (2009), Mathuva (2009), dan Dietrich and Wanzenried (2011) yang menemukan Biaya Operasional terhadap Pendapatan Operasional berpengaruh negatif terhadap kinerja.

Loan to Deposit Ratio (LDR) merupakan rasio likuiditas antara jumlah kredit yang diberikan terhadap total dana pihak ketiga (Kasmir, 2012: 290). Semakin tinggi Loan to Deposit Ratio, maka akan berdampak pada rendahnya likuiditas suatu bank dan meningkatnya kondisi bermasalah pada bank. Penelitian yang dilakukan oleh Setyarini (2009), dan Gul et. al (2011) menunjukkan bahwa Loan to Deposit Ratio berpengaruh positif terhadap kinerja keuangan. Penelitian yang dilakukan oleh Constantinos and Sofoklis (2009) menunjukkan bahwa Loan to Deposit Ratio berpengaruh negatif dan signifikan terhadap kinerja keuangan.

Capital Adequacy Ratio (CAR) mencerminkan kemampuan bank dalam pengelolaan dana yang digunakan untuk meminimalisir kerugian pada bank. (Kuncoro dan Suhardjono, 2002: 562). Semakin tinggi Capital Adequacy Ratio, maka semakin baik kemampuan bank dalam menghadapi risiko kerugian dan menunjukkan besarnya modal yang dimiliki oleh bank.
Penelitian yang telah dilakukan oleh Setyarini (2009), Mathuva (2009), dan Ali and Ahsan (2011) menunjukkan bahwa Capital Adequacy Ratio berpengaruh positif terhadap kinerja keuangan. Penelitian yang dilakukan Dietrich and Wanzenried (2011), dan Gul et al. (2011) menunjukkan hasil yang berbeda yaitu Capital Adequacy Ratio berpengaruh negatif terhadap kinerja keuangan.

Adanya tingkat persaingan yang semakin ketat yang terjadi antar bank membuat sektor perbankan harus merubah cara menjalankan usahanya ke arah knowledge based business. Knowledge based business memberikan penekanan pada peranan strategis ilmu pengetahuan (Sveiby, 2001), dan wujud perkembangan ilmu pengetahuan tersebut mendorong lahirnya Intellectual Capital (IC). Intellectual Capital terdiri dari pengetahuan, informasi, dan pengalaman yang digunakan untuk menciptakan kekayaan (Stewart, 1997). Adanya Intellectual Capital pada sektor perbankan ikut berperan serta di dalam peningkatan kinerja bank (Bontis et al., 2000; Belkaoui, 2003; Chen et al., 2005; Tan et al., 2007). Intellectual Capital juga tidak hanya mempengaruhi kinerja keuangan bank, tetapi juga dapat memprediksi kinerja pasar (Firer and Williams, 2003; Chen et al., 2005; Belkaoui, 2003; Wang, 2011; dan di Indonesia ada penelitian Astuti dan Sabeni, 2005; Ulum, 2008).

Permatasari (2018) menyatakan bahwa bank dengan Intellectual Capital rendah diharapkan dapat melakukan pengelolaan dan memanfaatkan Intellectual Capital dengan efisien dan efektif dan diharapkan dapat menciptakan value creation yang bersifat immobility dan berdampak pada pe- 
ningkatan kinerja keuangan. Sedangkan, pada bank dengan Intellectual Capital tinggi diharapkan kemampuan pengelolaan Intellectual Capital semakin tinggi, sehingga kinerja suatu bank dapat semakin baik dan dapat meningkatkan kinerja keuangan bank. Bank dengan Intellectual Capital tinggi juga lebih diminati oleh para investor. Hal ini disebabkan karena investor tersebut lebih suka menanamkan modalnya (Chen et al., 2005).

Penelitian ini dimaksudkan untuk mendapatkan jawaban mengenai 2 hal. Pertama untuk mengetahui apakah Non Performing Loan (NPL), Biaya Operasional Per Pendapatan Operasional (BOPO), Loan to Deposit Ratio (LDR), dan Capital Adequacy Ratio (CAR) berpengaruh terhadap kinerja keuangan pada bank dengan Intellectual Capital rendah? Kedua untuk mengetahui apakah apakah Non Performing Loan (NPL), Biaya Operasional Per Pendapatan Operasional (BOPO), Loan to Deposit Ratio (LDR), dan Capital Adequacy Ratio (CAR) berpengaruh terhadap kinerja keuangan pada bank dengan Intellectual Capital tinggi?

\section{TINJAUAN PUSTAKA}

\section{Intermediary Function}

Faktor-faktor yang dapat mempengaruhi intermediary function pada bank adalah sebagai berikut:

1. Non Performance Loan (NPL)

Non performance loan merupakan perbandingan antara kredit bermasalah terhadap total kredit (Kasmir, 2012: 292).

2. Loan to Deposit Ratio (LDR)

Loan to Deposit Ratio merupakan rasio likuiditas antara jumlah kredit yang diberikan terhadap total dana pihak ketiga. Kredit merupakan kre- dit yang diberikan kepada pihak ketiga (Kasmir, 2016: 225).

3. Beban Operasional terhadap Pendapatan Operasional (BOPO)

Biaya operasional terhadap pendapatan operasional merupakan perbandingan antara beban operasional dengan pendapatan operasional (Dendawijaya, 2005).

4. Capital Adequacy Ratio (CAR) Capital Adequacy Ratio adalah perbandingan antara modal sendiri dibagi dengan aset tertimbang menurut risiko (Riyadi, 2009: 161).

\section{Intellectual Capital (IC)}

Pulic (1998) menyatakan bahwa Intellectual Capital dapat diukur dengan menggunakan metode $\mathrm{VAIC}^{\mathrm{TM}}$. Berikut ini formula yang digunakan untuk menghitung VAIC ${ }^{\mathrm{TM}}$ :

VAIC $^{\text {TMit }}=$ VACA $_{\text {it }}+$ VAHU $_{\text {it }}+$ STVA $_{\text {it }}$

Menghitung VAICTM dapat dilakukan melalui 4 langkah berikut ini:

a. Menghitung value added (VA) dengan menggunakan rumus:

$$
\mathrm{VA}_{\mathrm{it}}=\mathrm{OUTPUT}_{\mathrm{it}}-\mathrm{INPUT}_{\text {it }}
$$

di mana:

OUTPUT $=$ pendapatan bunga dan pendapatan operasional lainnya

INPUT $=$ beban bunga, beban operasional, kecuali beban gaji dan tunjangan

b. Menghitung Value Added Capital Employed (VACA)

$\mathrm{VACA}_{\mathrm{it}}=\mathrm{VA}_{\mathrm{it}} / \mathrm{CE}_{\mathrm{it}}$

di mana: 


$$
\begin{aligned}
\mathrm{VACA}_{\mathrm{it}}= & \text { Value Added Capital } \\
& \begin{array}{l}
\text { Employed pada periode } \\
\mathrm{t}
\end{array} \\
\mathrm{VA}_{\mathrm{it}}= & \begin{array}{l}
\text { Value added pada pe- } \\
\text { riode } \mathrm{t}
\end{array} \\
\mathrm{CE}_{\mathrm{it}}= & \begin{array}{l}
\text { total ekuitas pada pe- } \\
\text { riode } \mathrm{t}
\end{array}
\end{aligned}
$$

c. Menghitung Value Added Human Capital (VAHU)

$$
\mathrm{VAHU}_{\mathrm{it}}=\mathrm{VA}_{\mathrm{it}} / \mathrm{HC}_{\mathrm{it}}
$$

di mana:

$\mathrm{VAHU}_{\mathrm{it}}=$ Value Added Human Capital pada periode $\mathrm{t}$

$\mathrm{VA}_{\mathrm{it}}=$ Value Added pada periode $\mathrm{t}$

$\mathrm{HC}_{\mathrm{it}}=$ beban gaji dan tunjangan pada periode $t$

d. Menghitung Structural Capital Value Added (STVA)

$\mathrm{STVA}_{\mathrm{it}}=\mathrm{SC}_{\mathrm{it}} / \mathrm{VA}_{\mathrm{it}}$

di mana:

$\mathrm{STVA}_{\mathrm{it}}=$ Structural Capital Value Added pada periode $\mathrm{t}$

$\mathrm{SC}_{\mathrm{it}}=$ Structural Capital pada periode $\mathrm{t}$ yang berasal dari $\mathrm{VA}_{\mathrm{it}}-\mathrm{HC}_{\mathrm{it}}$

$\mathrm{VA}_{\mathrm{it}}=$ Value Added pada periode $\mathrm{t}$

\section{Return on Equity (ROE)}

Return on equity didefinisikan secara umum sebagai perbandingan antara pendapatan bersih setelah pajak dengan jumlah modal sendiri yang digunakan utuk menghasilkan laba tersebut (Brigham and Houston, 2001: 133).

\section{METODE PENELITIAN}

Penelitian ini merupakan penelitian kuantitatif yang didasarkan pada data sekunder. Populasi penelitian ini adalah perusahaan perbankan yang terdaftar di Bursa Efek Indonesia dan pengolahan datanya dilakukan dengan menggunakan Statistical Package for Social Sciences (SPSS). Berdasarkan populasi yang sudah ditentukan, maka penentuan sampel dalam penelitian ini menggunakan metode purposive sampling, dengan mengunakan kriteria sebagai berikut:

1. Perusahaan perbankan yang terdaftar di Bursa Efek Indonesia periode 2010 sampai dengan 2016.

2. Perusahaan perbankan yang memiliki laporan keuangan lengkap dan jelas dari periode 2010 sampai dengan 2016 (termasuk di dalamnya perbankan yang melakukan merger dan akuisisi).

3. Perusahaan tidak dalam kondisi suspend atau delisting.

Variabel yang digunakan dalam penelitian ini adalah variabel independen yang meliputi Non Performing Loan (NPL), Biaya Operasional Per Pendapatan Operasional (BOPO), Loan To Deposit Ratio (LDR), dan Capital Adequacy Ratio (CAR). Sedangkan variabel dependen yang meliputi Return on Equity (ROE). Analisis data yang digunakan pada penelitian ini menggunakan analisis regresi linier, dengan model penelitian:

$\mathrm{ROE}_{\text {it }}=\alpha_{0}+\beta_{11} \mathrm{NPL}_{\mathrm{it}}+\beta_{12} \mathrm{BOPO}_{\text {it }}$ $+\beta_{13} \mathrm{LDR}_{\text {it }}+\beta_{14}$ CARit $+\varepsilon_{\text {it }}$

\section{HASIL DAN PEMBAHASAN}

Sampel yang digunakan pada penelitian ini adalah sebanyak dua puluh tiga perusahaan, di mana jumlah perusahaan perbankan yang tercatat di Bursa Efek Indonesia dari 2010 sampai dengan 2016 adalah tiga puluh tiga perusahaan. Perusahaan perbankan yang tidak memiliki data lengkap pada 
penelitian ini adalah empat perusahaan dan perusahaan perbankan yang $d e-$ listing adalah sebesar enam perusahaan. Berikut ini adalah hasil pengolahan data penelitian:

Tabel 1

Hasil F hitung

\begin{tabular}{|c|c|c|}
\hline Keterangan & $\begin{array}{c}\text { ROE IC } \\
\text { Rendah }\end{array}$ & $\begin{array}{c}\text { ROE IC } \\
\text { Tinggi }\end{array}$ \\
\hline F hitung & 2,458 & 17,614 \\
\hline & $(0,053)$ & $(0,000)$ \\
\hline
\end{tabular}

Sumber: Data Diolah

Tabel 2

Hasil $\mathbf{R}^{2}$

\begin{tabular}{|c|c|c|}
\hline Keterangan & $\begin{array}{c}\text { ROE IC } \\
\text { Rendah }\end{array}$ & $\begin{array}{c}\text { ROE IC } \\
\text { Tinggi }\end{array}$ \\
\hline $\mathrm{R}^{2}$ & 0,117 & 0,478 \\
\hline
\end{tabular}

Sumber: Data Diolah

Tabel 3

Hasil Regresi

\begin{tabular}{|l|c|c|}
\hline Keterangan & $\begin{array}{c}\text { ROE IC } \\
\text { Rendah }\end{array}$ & $\begin{array}{c}\text { ROE IC } \\
\text { Tinggi }\end{array}$ \\
\hline NPL & 0.095 & 0,707 \\
\hline & $(0,895)$ & $(0,889)$ \\
\hline BOPO & $-0,0362$ & $-0,078$ \\
\hline & $(0.006)$ & $(0,000)$ \\
\hline LDR & -0.028 & 0,004 \\
\hline CAR & $(0.644)$ & $(0,947)$ \\
\hline & -0.086 & $-0,444$ \\
\hline & $(0,656)$ & $(0,068)$ \\
\hline
\end{tabular}

Sumber: Data Diolah

Keterangan:

Tanda kurung merupakan nilai $p$ value

Pengaruh NPL, BOPO, LDR, dan CAR terhadap ROE pada bank dengan Intellectual Capital rendah

1. Non Performing Loan (NPL)

Hasil penelitian menunjukkan bahwa Non Performing Loan tidak berpengaruh terhadap Return on Equity pada bank dengan Intellectual $\mathrm{Ca}$ - pital rendah. Hal ini disebabkan karena investor tidak memasukan unsur Non Performing Loan sebagai bahan pertimbangan dalam melakukan investasi dan kurang efektifnya peranan Intellectual Capital. Hal ini disebabkan karena ada bank yang ada di Indonesia dibatasi oleh regulasi yang ditetapkan oleh Bank Indonesia. Hasil penelitian ini sejalan dengan penelitian yang dilakukan oleh Constantinos and Sofoklis (2009) dan Mawardi (2005).

2. Beban Operasi terhadap Pendapatan Operasional (BOPO)

Hasil penelitian menunjukkan bahwa Beban Operasi terhadap Pendapatan Operasional tidak berpengaruh terhadap Return on Equity pada bank dengan Intellectual Capital rendah. Hal ini menunjukkan bahwa sumber daya yang dimiliki oleh bank tersebut dikelola secara efisien dan efektif, sehingga dapat memperoleh keuntungan yang besar, mengingat Beban Operasi terhadap Pendapatan Operasional bertujuan meminimalisir risiko operasional. Hasil penelitian ini sejalan dengan penelitian yang dilakukan oleh Setyarini (2009), Constantinos and Sofoklis (2009), Mathuva (2009), Dietrich and Wanzenried (2011).

\section{Loan Deposit Ratio (LDR)}

Hasil penelitian menunjukkan bahwa Loan Deposit Ratio berpengaruh negatif dan tidak signifikan terhadap Return on Equity pada bank dengan Intellectual Capital rendah. Hal ini disebabkan karena bank kurang efektif dalam hal penyaluran kredit. Semakin kecil kredit yang disalurkan oleh bank akan mempengaruhi nilai Loan Deposit Ratio suatu bank. Hasil penelitian ini sejalan dengan penelitian yang 
dilakukan oleh Constantinos and Sofoklis (2009).

\section{Capital Adequacy Ratio (CAR)}

Hasil penelitian menunjukkan bahwa Capital Adequacy Ratio berpengaruh negatif dan signifikan terhadap Return on Equity pada bank dengan Intellectual Capital rendah. Hal ini disebabkan karena kurangnya kemampuan manajer dalam mengelola modal yang dimiliki bank dan kurangnya kemampuan memprediksi kemungkinan risiko kerugian yang ditimbulkan terhadap tingkat pendapatan, sehingga akan mempengaruhi kinerja bank. Hasil penelitian ini sejalan dengan penelitian yang dilakukan oleh Dietrich and Wanzenried (2011) dan Gul et al. (2011).

Pengaruh NPL, BOPO, LDR, dan CAR terhadap ROE pada bank dengan Intellectual Capital tinggi

\section{Non Performing Loan (NPL)}

Hasil penelitian menunjukkan bahwa Non Performing Loan tidak berpengaruh terhadap Return on Equity pada bank dengan Intellectual $\mathrm{Ca}$ pital tinggi. Hal ini disebabkan karena investor tidak memasukan unsur Non Performing Loan sebagai bahan pertimbangan dalam melakukan investasi dan kurang efektifnya peranan Intellectual Capital. Hal ini disebabkan karena bank yang ada di Indonesia dibatasi oleh regulasi yang ditetapkan oleh Bank Indonesia. Hasil penelitian ini sejalan dengan penelitian yang dilakukan oleh Constantinos and Sofoklis (2009) dan Mawardi (2005).

2. Beban Operasi terhadap Pendapatan Operasional (BOPO)

Hasil penelitian menunjukkan bahwa Beban Operasi terhadap Penda- patan Operasional berpengaruh negatif dan signifikan terhadap Return on Equity pada bank dengan Intellectual Capital tinggi. Hal ini menunjukkan bahwa semakin tinggi Intellectual Capital yang dimiliki oleh bank, maka semakin rendah Beban Operasi terhadap Pendapatan Operasional suatu bank. Hal ini disebabkan karena sumber daya yang dimiliki oleh bank tersebut dikelola secara efisien dan efektif sehingga dapat memperoleh keuntungan yang besar, mengingat Beban Operasi terhadap Pendapatan Operasional bertujuan meminimalisir risiko operasional. Hasil penelitian ini sejalan dengan penelitian yang dilakukan oleh Mathuva (2009), Setyarini (2009), Dietrich and Wanzenried (2011), dan Constantinos and Sofoklis (2009).

\section{Loan Deposit Ratio (LDR)}

Hasil penelitian menunjukkan bahwa Loan Deposit Ratio berpengaruh negatif dan signifikan terhadap $R e$ turn on Equity pada bank dengan Intellectual Capital tinggi. Hal ini disebabkan karena bank kurang efektif dalam memanfaatkan Intellectual Capital yang ada dan ketidakberhasilan manajer bank dalam mengelola penyaluran kredit. Semakin kecil kredit yang disalurkan oleh bank akan mempengaruhi nilai Loan Deposit Ratio suatu bank. Hasil penelitian ini sejalan dengan penelitian yang dilakukan oleh Constantinos and Sofoklis (2009).

4. Capital Adequacy Ratio (CAR)

Hasil penelitian menunjukkan bahwa Capital Adequacy Ratio berpengaruh negatif dan signifikan terhadap Return on Equity pada bank dengan Intellectual Capital tinggi. Hal ini disebabkan karena kurang- 
nya kemampuan manajer dalam memanfaatkan Intellectual Capital di dalam pengelolaan modal yang dimiliki bank dan kurangnya memprediksi kemungkinan risiko kerugian yang ditimbulkan terhadap tingkat pendapatan, sehingga akan mempengaruhi kinerja bank. Hasil penelitian ini sejalan dengan penelitian yang dilakukan oleh Dietrich and Wanzenried (2011), dan Gul et al. (2011).

\section{SIMPULAN}

1. Hasil pengujian pada bank dengan Intellectual Capital rendah dan Intellectual Capital tinggi menunjukkan bahwa Non Performing Loan (NPL), Biaya Operasional Per Pendapatan Operasional (BOPO,) Loan to Deposit Ratio (LDR), dan Capital Adequacy Ratio (CAR) tidak berpengaruh terhadap Return on Equity (ROE).

2. Hasil pengujian pada bank dengan Intellectual Capital tinggi dan Intellectual Capital tinggi menunjukkan bahwa Non Performing Loan (NPL), Loan to Deposit Ratio (LDR), dan Capital Adequacy Ratio (CAR) tidak berpengaruh terhadap Return on Equity (ROE).

3. Hasil pengujian pada bank yang memiliki Intellectual Capital tinggi menunjukkan bahwa Biaya Operasional Per Pendapatan Operasional (BOPO) berpengaruh terhadap $R e$ turn on Equity (ROE).

\section{SARAN}

Keterbatasan penelitian ini adalah hasil penelitian hanya dapat digunakan pada sektor perbankan yang go public di Bursa Efek Indonesia. Berdasarkan hal tersebut, maka saran untuk penelitian selanjutnya adalah sampel yang digunakan mencakup seluruh perusahaan perbankan yang ada di Indonesia, tanpa membedakan yang go public atau tidak.

\section{DAFTAR KEPUSTAKAAN}

Ali, Masyhud, 2004, Asset Liability Management: Menyiasati Risiko Pasar dan Risiko Operasional, PT Gramedia, Jakarta.

Ali, Qurban and Muhammad Ahsan, 2011, Estimation of Variability and Correlation Analysis for Quantitative Traits in Chickpea (Cicer arietinum L.), IJAVMS, Vol. 5, Issue 2, pages 194-200.

Allen, Franklin, A. Santomomero, 1998, The Theory of Financial Intermediation, Journal of Banking and Finance, Vol. 21, pages 14611485.

Alper, Deger and Adem Anbarb, 2011, Bank Specific and Macroeconomic Determinants of Commercial Bank Profitability: Empirical Evidence from Turkey, Business and Economics Research Journal, Vol. 2, No. 2, pages 139-152.

Anggadini, 2010, Kasus Fee Based Income Dampaknya terhadap Profitabilitas, Studi Kasus Pada PT. Bank Negara Indonesia (Persero) Tbk, Jurnal Bisnis, Manajemen dan Ekonomi, Vol. 9, No. 9, hal. 22512260.

Ariani, Citra, 2009, Analisis pengaruh Free Cash Flow dan Kepemilikan Manajerial Terhadap kebijkan Hutang dan Retirn Saham Pada Perusahaan yang Terdaftar di Bursa Efek Indonesia, STIE Perbanas, Surabaya. 
Ariyanto, Taufik, 2004, Profil Persaingan Usaha Dalam Industri Perbankan Indonesia, Komisi Pengawas Persaingan Usaha (KPPU), Jakarta.

Astuti, Partiwi Dwi dan Arifin Sabeni, 2005, Hubungan Intellectual Capital dan Business Performance dengan Diamond Specification: Sebuah Perspektif Akuntansi, Simposium Nasional Akuntansi VIII, Solo, hal. 694-707.

Banz, Rolf W., 1981, The Relationship Between Return and Market Value of Common Stocks, Journal of Financial Economics, Vol. 9, pages 3-18.

Barney, J. B., 1986, Strategic Factors Market: Expectations, Luck and Business Strategy, Management Science, Vol. 32, Issue 10, pages 1231-1242.

Basuki and Mutiara Sianipar, 2012, Intellectual Capital and Its Impact on Financial Profitability and Investors' Capital Gain on Shares, Journal of Economics, Business, and Accountancy Ventura, Vol. 15, No. 1, pages 101-116.

Belkaoui, A. R., 2003, Intellectual Capital and Firm Performance of US Multinational Firms: A Study of The Resource-Based and Stakeholder Views, Journal of Intellectual Capital, Vol. 4, No. 2, pages 215226.

Bencivenga, V. R., B. D. Smith, 1991, Financial Intermediation and Endogenous Growth, Review of Economic Studies, Vol. 58, pages 195209.
Bontis, N., W. C. C. Keow and S. Richardson, 2000, Intellectual Capital and Business Performance in Malaysian Industries, Journal of Intellectual Capital, Vol. 1, pages 85-100.

Brigham, Eugene $\mathrm{F}$ and Joel $\mathrm{F}$. Houston, 2001, Manajemen Keuangan II, Salemba Empat, Jakarta.

Busch, R. and T. Kick, 2009, Income Diversification in the German Banking Industry, Deutsche Bundesbank, Discussion Paper Series 2: Banking and Financial Studies No. 09/2009, pages 1-17.

Chen, M. C., S. J. Cheng, and Y. Hwang, 2005, An Empirical Investigation of the Relationship between Intellectual Capital and Firm's Market Value and Financial Performance, Journal of Intellectual Capital, Vol. 6, No. 2, pages 159176.

Constantinos, A. and V. Sofoklis, 2009, Determinants Of Bank Profitability: Evidence From The Greek Banking Sector, Economic Annals, Volume LIV, pages 182-194.

Dendawijaya, Lukman, 2005, Manajemen Perbankan, Edisi Kedua, Ghalia Indonesia, Bogor.

Diamond, D. W., 1984, Financial Intermediation and Delegated Monitoring, Review of Economic Studies, Vol. 51, pages 393-414.

Dietrich, Andreas and Gabrielle Wanzenried, 2011, What Determines the Profitability of Commercial Banks? New Evidence from Switzerland, Journal of International Financial 
Markets, Institutions and Money, Vol. 21, Issue 3, pages 307-327.

Fama, E. F. and K. R. French, 1992, The Cross-Section of Expected Stock Returns, The Journal of Finance, Vol. 42, No. 2, pages 427465.

Firer, S. and S. M. Williams, 2003, Intellectual Capital and Traditional Measures of Corporate Performan$c e$, Journal of Intellectual Capital, Vol. 4, No. 3, pages 348-360.

Gischer, Horst and Dieter Johannes P. Juttner, 2003, Global Competition and Interest Rate Margins of Banks, Kredit und Kapital-Berlin: Duncker \& Humblot, Vol. 36, No. 3, pages 368-394.

Gitman, Lawrence, 2014, Principles of Manajerial Finance, Pearson Addison Wesley, United States.

Grant, Robert M., 1997, The Knowledge-based View of the Firm: Implications for Management Practice, Long Range Planning, Vol. 30, No. 3, pages 450-454.

Gul, Sehrish, Faiza Irshad, and Khalid Zaman, 2011, Factors Affecting Bank Profitability in Pakistan, The Romanian Economic Journal, 14 (39), pages 61- 87.

Haneef, S., Tabassum Riaz, Muhammad Ramzan, Mansoor Ali Rana, Hafiz Muhammad Ishaq, Yasir Karim, 2012, Impact of Risk Management on Non-Performing Loans And Profitability of Banking Sector of Pakistan, International Journal of Business and Social Science, Vol. 3, No. 7, pages 307-315.
Hermawan, Sigit dan B. Maharis Wahyuaji, 2013, Analisis Pengaruh Intellectual Capital terhadap Kemampulabaan Perusahaan Manufaktur Costumer Goods di Bursa Efek Indonesia, Call for Paper Bidang Akuntansi, hal. 271-282.

Hidayati, N., 2009, Pengaruh Struktur Kepemilikan, Profitabilitas, Ukuran Perusahaan, Pertumbuhan Aktiva, dan Risiko Bisnis Terhadap Struktur Modal Studi Pada Perusahaan yang Masuk Kelompok Jakarta Islamic Index Tahun 2005-2007, Bisnis Strategi, Vol. 19, No. 2, hal. 166-174.

Hong, Fang, and H. China, 2010, An Emporocal Research on the Relationship Between Non Interest Income Business and Operation Performance of Comercial Banks, Proceedings of the $7^{\text {th }}$ International Conference on Innovation \& Management, pages 1477-1481.

Jelali, Mohieddine and Biao Huang, 2010, Detection and Diagnosis of Stiction in Control Loops: State of the Art and Advanced Method, Springer.

Kabajeh, Majed Abdel Majid, Said Mukhled Ahmed Al Nu'aimat, and Firas Naim Dahmash, 2012, The Relationship between the ROA, ROE, and ROI Ratios with Jordanian Insurance Public Companies Market Share Prices, International Journal of Humanities and Social Science, Vol. 2, No. 11, pages $115-120$.

Kasmir, 2012, Analisis Laporan Keuangan, PT RajaGrafindo Persada, Jakarta. 
2016, Analisis Laporan Keuangan, PT RajaGrafindo Persada, Jakarta.

Koch, Timothy W. and Scott MacDonald, 2000, Bank Management, 4th Edition, Hartcourt College Publishers, Orlando.

\section{4, Bank Manage-}

ment, Eight Edition, South Western Publishing, United States of America.

Krasa, Stefan and Anne P. Villamil, 1992, Monitoring The Monitor: An Incentive Structure for a Financial Intermediary, Journal of Economics Theory, Vol. 57, pages 197-221.

Kuncoro dan Suhardjono, 2002, Manajemen Perbankan (Teori dan Aplikasi), Edisi Pertama, Penerbit BPFE, Yogyakarta.

Lartey, Antawi, and Boadi, 2003, The Relationship Between Net Interest Margin and Return On Assets of Listed Banks in Ghana, Research Journal of Finance and Accounting, Vol. 4, No. 16, pages 73-78.

Leland, Hayne E. and David H. Pyle, 1997, Informational Asymmetries, Financial Structure, and Financial Intermediation, The Journal of Finance, Vol. 32, No. 2, pages 371387.

Levine, Ross, 1996, Financial Development and Economic Growth: View and Agenda, Journal of Economic Literature, Vol. 35, pages 688-726.

Mathuva, D. M., 2009, The Influence of Working Capital Management Components on Corporate Profit- ability: A survey on Kenyan Listed Firms, Research Journal of Business Management, Vol. 4 (1), pages $1-11$.

Mavridis, Dimitrios G., 2004, The Intellectual Capital Performance of the Japanese Banking Sector, Journal of Intellectual Capital, Vol. 5 Issue 1, pages 92-115.

Mawardi, Wisnu, 2005, Analisis Faktor-faktor yang Mempengaruhi Kinerja Keuangan Bank Umum di Indonesia (Studi Kasus pada Bank Umum dengan Total Aset Kurang dari 1 Triliun), Jurnal Bisnis Strategi, Vol. 14, No. 1, hal. 83-94.

Megginson, William, 1997, Corporate Finance Theory, AddisonWisley Education Publisher Inc.

Moeheriono, 2012, Pengukuran Kinerja Berbasis Kompetensi, RajaGrafindo Persada, Jakarta.

Parung, Joniarto, 2008, Peranan Modal Intelektual dalam Kerjasama Bisnis untuk Penciptaan Nilai Rantai Pemasok (Supply Chain Value), Jurnal Manajemen Teknologi, Vol 7, No. 1, hal. 46-57.

Pennathur, Anita K., Vijaya Subrahmanya, and Sharmila Vishwasrao, 2012, Income Diversification and Risk: Does Ownership Matter? An Empirical Examination of Indian Banks, Journal of Banking \& Finance, Vol. 36, Issue 8, pages 2203-2215.

Permatasari, Anita, 2018, Peranan Intellectual Capital terhadap Fungsi Perbankan: Studi di Bursa Efek Indonesia, Disertasi, Universitas Widya Mandala, Surabaya. 
Peteraf, 1993, The Cornerstones of Competitive Advantage: A Resource-Based View, Strategic Management Journal, Vol. 14, pages 179191.

Peters, D., E. Raad, and J. F. Sinkey, 2004, The Performance of Banks in Post-war Lebanon, International of Business 9 (3), pages 259-286.

Pontiff, Jeffrey and Lawrence D. Schall, 1998, Book-to-Market Ratios as Predictors of Market Returns, Journal of Financial Economics 49, pages 141-160.

Prahalad, C. K. and G. Hamel, 1990, The Core Competence of the Corporation, Harvard Bussiness Review, 68 (3), pages 79-91.

Pulic, A., 1998, Measuring The Performance of Intellectual Potential in Knowledge Economy, Makalah ini Dipresentasikan pada 2nd McMaster Word Congress on Measuring and Managing Intellectual Capital by the Austrian Team for Intellectual Potential. 2000, VAIC ${ }^{T M}$ - an Accounting Tool for IC Management, International Journal Technology Management, Vol. 20, pages 702-714.

Rachmawati, Damar Asih Dwi, 2012, Pengaruh Intellectual Capital terhadap Return On Asset (ROA) Perbankan, Jurnal Nominal, Vol. 1, No. 1.

Rajan, Raghuram G., 1992, Insider and Out-siders: The Choice between Informed and Arm's-Length Debt, Journal Finance 47, pages 1367-1400.
Rajan, Raghuram G. and Luigi Zingales, 1998, Financial Dependence and Growth, American Economic Review, pages 559-586.

Rindjin, Ketut, 2000, Pengantar Perbankan dan Lembaga Keuangan Bukan Bank, PT SUN, Jakarta.

Riyadi, Slamet, 2009, Banking Assets and Liability Management, Lembaga Penerbit Fakultas Ekonomi Universitas Indonesia, Jakarta.

Rubhyanti, R., 2008, Hubungan antara Modal Intelektual dengan Nilai Pasar dan Kinerja Keuangan, KOMPAK 1 (1), hal. 55-61.

Santosa, Setyarini, 2012, Pengaruh Modal Intelektual dan Pengungkapannya Terhadap Kinerja Perusahaan, Jurnal Akuntansi dan Keuangan, Vol. 14, No. 1, hal. 16-31.

Santoso, Singgih, 2012, Panduan Lengkap SPSS Versi 20, PT Elex Media Komputindo, Jakarta.

Saunders, A. and I. Walters, 1994, Universal banking in the United States: What Could We Gain? What Could We Lose?, NY: Oxford University Press, New York.

Scholtens, Bert and Dick van Wensveen, 2003, The Theory Of Financial Intermediation: An Essay On What It Does (Not) Explain, SUERF - The European Money and Finance Forum Vienna 2003.

Sensarma, Rudra and Saurabh Ghosh, 2004, Net Interest Margin: Does Ownership Matter?, VIKALPA, Vol. 29, No. 1.

Setiadi, P. B., 2010, Analisis Hubungan Spread of Interest Rate, Fee Based Income, dan Loan to Deposit 
Ratio dengan ROA Pada Perbankan di Jawa Timur, Jurnal Mitra Ekonomi dan Manajemen Bisnis, Vol. 1, No. 1, hal. 63-82.

Setyarini, 2009, Analisis Pengaruh CAR, NIM, BOPO, LDR, GWM Terhadap Perubahan Laba (Studi pada Bank Pembangunan Daerah di Indonesia Periode 2005-2007), Thesis, Program Studi Magister Manajemen Universitas Diponegoro.

Shane, S., 2000, Prior Knowledge and The Discovery of Entrepreneurial Opportunities, Organization Science, pages 448-469.

Sharpe, S. A., 1990, Asymmetric Information, Bank Lending and Implicit Contracts: A Stylized Model of Customer Relationships, Journal of Finance 45, pages 1069-1087.

Sidabutar, S. P., 2007, Analisis Pengaruh Kepemilikan Institusi, Net Profit Margin, Debt To Equity Ratio, dan Rasio-Rasio Bank Terhadap Return on equity (Studi Empiris: Perusahaan Perbankan yang Listed di BEJ Periode 2003-2005, Tesis, Program Pasca Sarjana Magister Manajemen Universitas Diponegoro (tidak dipublikasikan).

Sinaga, Dianto Kurnia Parulian, 2011, Pengaruh Tingkat Kesehatan Bank Berdasarkan Metode Camel Terhadap Return Saham Pada Industri Perbankan di Indonesia Stock Exchange (IDX), Thesis, Program Magister Akuntansi, Universitas Bina Nusantara, Jakarta.

Sinkey, Joseph F., 2002, Commercial Bank Financial Management in The
Financial Services Industry, Prentice Hall, New Jersey.

Solikhah, Badingatus, Abdul Rohman, and Wahyu Meiranto, 2010, Implikasi Intellectual Capital terhadap Financial Performance, Growth dan Market Value; Studi Empiris dengan Pendekatan Simplisitic Specification, Makalah Disampaikan dalam Simposium Nasional Akuntansi XIII, Purwokerto.

Spence, M., 2002, Signaling in Retrospect and The Informational Structure of Markets, American Economic Review, Vol. 92, Issue 3, pages 434-459.

Stewart, T., 1997, Intellectual Capital: The New Wealth Of Organizations, Nicholas Brealey Publishing, Business Digest, New York.

Sudibya, Diva Cicilya Nunki Arun dan MI Mitha Dwi Restuti, 2014, Pengaruh Modal Intelektual Terhadap Nilai Perusahaan Dengan Kinerja Keuangan Sebagai Variabel Intervening, Benefit Jurnal Manajemen dan Bisnis, Vol. 18, No. 1, hal 14-29.

Sufian, Fadzlan, 2011, Benchmarking The Efficiency of The Korean Banking Sector: A DEA Approach, Benchmarking, An International Journal, Vol. 18 Issue 1, pages 107127.

Sunarsih, N. M. dan Ni Putu Yuria Mendra, 2012, Pengaruh Modal Intelektual Terhadap Nilai Perusahaan Dengan Kinerja Keuangan sebagai Variabel Intervening pada Perusahaan yang Terdaftar Di Bursa Efek Indonesia, Makalah Disam- 
paikan dalam Simposium Nasional Akuntansi XV, Banjarmasin.

Sveiby, Karl-Erik, 2001, A Knowledge Based Theory of the Firm to Guide in Strategy Formulation, Journal of Intellectual Capital, Vol. 2, No. 4, pages 344-358.

Tan, H. P., D. Plowman, and P. Hancock, 2007, Intellectual Capital and Financial Returns of Companies, Journal of Intellectual Capital, Vol. 8, No. 1, pages 76-95.

Ulum, Ihyaul, 2008, Intellectual Capital Performance Sektor Perbankan di Indonesia, Jurnal Akuntansi dan Keuangan, Vol. 10, No. 2, hal. 7784.

Wang, M., 2011, Measuring Intellectual Capital and Its Effect on Financial Performance, Journal of Research Article Higher Education Press and Springer-Verlag 2011, Taiwan, pages 243-265.
Warnerfelt, B., 1984, A ResourceBased View of The Firm, Strategic Management Journal, Vol. 2, No. 5, pages 171-180.

Whiting, Rosalind H. and James C. Miller, 2008, Voluntary Disclosure of Intellectual Capital in New Zealand Annual Reports and The "Hidden Value", Journal of Human Resource Costing and Accounting, Vol. 12, No. 1, pages 26-50.

Williamson, Stephen D., 1986, Costly Monitoring, Financial Intermediation, and Equilibrium Credit Rationing, Journal of Monetary Economics, Vol. 18, No. 2, pages 159179. 